Article

\title{
Polyacetylenes from the Roots of Swietenia macrophylla King
}

\author{
Cheng-Neng Mi ${ }^{1,2}$, Hao Wang ${ }^{1} \mathbb{D}$, Hui-Qin Chen ${ }^{1}$, Cai-Hong Cai ${ }^{1}$, Shao-Peng $\mathrm{Li}^{2}$, \\ Wen-Li Mei ${ }^{1, *}$ and Hao-Fu Dai ${ }^{1, *}$ \\ 1 Key Laboratory of Biology and Genetic Resources of Tropical Crops, Ministry of Agriculture, \\ Institute of Tropical Bioscience and Biotechnology, Chinese Academy of Tropical Agricultural Sciences, \\ Haikou 571101, China; michengnengnpc@126.com (C.-N.M.); wanghao@itbb.org.cn (H.W.); \\ chenhuiqin@itbb.org.cn (H.-Q.C.); caicaihong@itbb.org.cn (C.-H.C.) \\ 2 Institute of Tropical Agriculture and Forestry, Hainan University, Haikou 570228, China; lisp555@126.com \\ * Correspondence: meiwenli@itbb.org.cn (W.-L.M.); daihaofu@itbb.org.cn (H.-F.D.); \\ Tel.: +86-898-6698-7529 (W.-L.M.); +86-898-6696-1869 (H.-F.D.)
}

Academic Editor: Alessandra Guerrini

Received: 22 February 2019; Accepted: 22 March 2019; Published: 2 April 2019

check for updates

\begin{abstract}
A phytochemical investigation of the roots of Swietenia macrophylla led to the isolation of seven polyacetylenes, including five new compounds (1-5) and two known ones (6-7). Their structures were elucidated by extensive spectroscopic analysis and detailed comparison with reported data. All the isolates were tested for their cytotoxicity against the human hepatocellular carcinoma cell line BEL-7402, human myeloid leukemia cell line K562, and human gastric carcinoma cell line SGC-7901. Compounds $\mathbf{1}$ and $\mathbf{6}$ showed moderate cytotoxicity against the above three human cancer cell lines with $\mathrm{IC}_{50}$ values ranging from 14.3 to $45.4 \mu \mathrm{M}$. Compound 4 displayed cytotoxicity against the K562 and SGC-7901 cancer cell lines with $\mathrm{IC}_{50}$ values of $26.2 \pm 0.4$ and $21.9 \pm 0.3 \mu \mathrm{M}$, respectively.
\end{abstract}

Keywords: Swietenia macrophylla; roots; polyacetylene; cytotoxicity

\section{Introduction}

Natural polyacetylenes, structures featuring two or more triple bonds [1], are mainly found in plants belonging to the Araliaceae [2-7], Asteraceae [8-10], Umbelliferae [11-13], Santalaceae [14], Pittosporaceae [15], and Oleaceae [16] families. However, polyacetylenes are uncommon in the Meliaceae family, with only six such compounds having been found in total in this family, one of which is from Swietenia mahagoni [17], three from Toona ciliate [18], and two from the stem bark of Khaya ivorensis A. Chev $[19,20]$. Naturally occurring polyynes are classified into four types: acyclic $\mathrm{C}_{18}-\mathrm{C}_{14}$ acetylene compounds; acyclic $\mathrm{C}_{13}-\mathrm{C}_{8}$ acetylene compounds; compounds with an allene substructure; and aromatic and heterocyclic acetylene compounds [1]. Diverse polyacetylene structures exhibit a series of bioactivities, including cytotoxicity $[8,10,11,21]$ and antimicrobial $[14,22,23]$, antiviral [24], and enzyme-inhibitory [6,25] activities.

Swietenia macrophylla, a perennial deciduous timber tree that reaches a height of up to $50 \mathrm{~m}$ [26], is native to Central and South America [27] and widely distributed in West India, Malaysia, and southern China [28,29]. Antecedent chemical investigations on S. macrophylla have focused mostly on the aboveground parts and their bioactive limonoids [30]. It is necessary to expand the scope of research on S. macrophylla and discover or develop additional biologically active constituents of this plant genus [31]. Our recent study on the roots of S. macrophylla led to the isolation of a series of xanthones, limonoids, and other chemical components [32,33]. As a continuation of our studies on the biologically active agents from this plant, five new and two known acyclic $C_{18}-C_{14}$ polyacetylenes have been further isolated here, and their cytotoxic activities against the human hepatocellular carcinoma 
cell line BEL-7402, human myeloid leukemia cell line K562, and human gastric carcinoma cell line SGC-7901 were investigated. In this paper, the isolation, structural elucidation, and cytotoxicity of these compounds are reported as follows.

\section{Results and Discussion}

The chemical examination of the ethyl acetate (EtOAc) extract from the roots of $S$. macrophylla resulted in the isolation and identification of five new polyacetylenes (Figure 1), respectively named heptadeca-9-ene-4,6-diyne-3,11-diol (1), (E)-heptadeca-8-ene-4,6-diyne-3,10,11-triol (2), 10-methoxyheptadeca-4,6-diyne-3,9-diol (3), tetradeca-1,3-diyne-6,7,8-triol (4) and 6,7,8,9tetraacetoxytetradeca-1,3-diyne (5), together with two known compounds, which were identified as $\alpha$-hexy-3-(6-hydroxy-2,4-ocadiynyl)oxiranemethanol (6) [17] and ( $3 R, 8 E, 10 S)$-heptadec-8-ene-4,6diyne-3,10-diol (7) [18] by comparing their experimental spectroscopic data with the reported data in the literature. HRESIMS and NMR spectra for compounds $\mathbf{1 - 5}$ are shown in the Supplementary Materials.
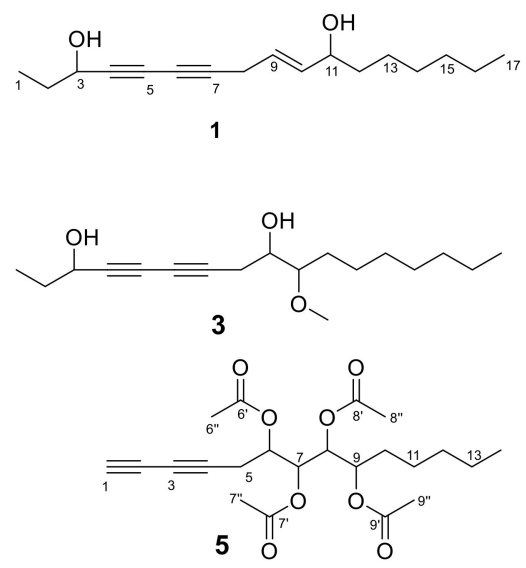
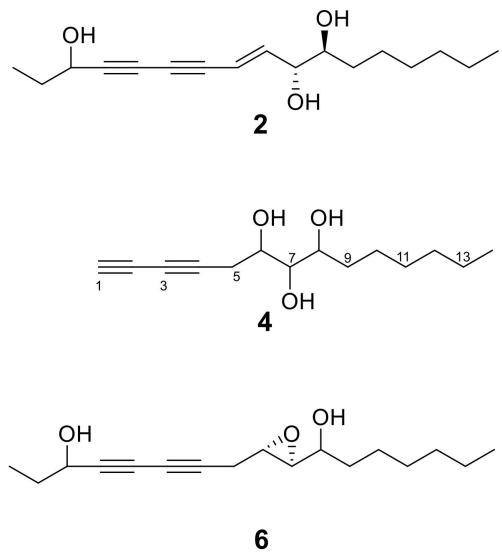

$\mathrm{OH}$

7

Figure 1. Structures of compounds 1-7.

Compound 1 was obtained as a yellow oil with a positive optical rotation $[\alpha]_{\mathrm{D}}^{25}+10\left(c 0.1, \mathrm{CH}_{3} \mathrm{OH}\right)$ and has a molecular formula of $\mathrm{C}_{17} \mathrm{H}_{26} \mathrm{O}_{2}$, as evidenced by the HRESIMS peak at $\mathrm{m} / z 285.1830$ $[\mathrm{M}+\mathrm{Na}]^{+}$(calcd 285.1831 for $\mathrm{C}_{17} \mathrm{H}_{26} \mathrm{NaO}_{2}$ ), requiring five unsaturation degrees. The UV spectrum displayed typical absorption bands for a conjugated ene-yne-yne chromophore at $\lambda_{\max } 280$ and $270 \mathrm{~nm}$ [11], and the IR spectrum showed the OH group $\left(3435 \mathrm{~cm}^{-1}\right)$, triple-bond $\left(2234 \mathrm{~cm}^{-1}\right)$, and olefinic double-bond $\left(1639 \mathrm{~cm}^{-1}\right)$ absorptions. The ${ }^{1} \mathrm{H}-\mathrm{NMR}$ data (Table 1) showed the presence of two olefinic protons at $\delta_{\mathrm{H}} 5.50(1 \mathrm{H}, \mathrm{m}$, overlapped, $\mathrm{H}-9)$ and $5.48(1 \mathrm{H}, \mathrm{m}$, overlapped, $\mathrm{H}-10)$; two oxymethine protons, which appeared at $\delta_{\mathrm{H}} 4.34(1 \mathrm{H}, \mathrm{t}, J=6.4 \mathrm{~Hz}, \mathrm{H}-3)$ and $4.39(1 \mathrm{H}, \mathrm{q}, J=6.7 \mathrm{~Hz}$, $\mathrm{H}-11)$; two triplet methyl groups at $\delta_{\mathrm{H}} 0.99(3 \mathrm{H}, \mathrm{t}, J=7.4 \mathrm{~Hz}, \mathrm{H}-1)$ and $0.87(3 \mathrm{H}, \mathrm{t}, J=6.8 \mathrm{~Hz}, \mathrm{H}-17)$; and fourteen aliphatic methylene protons at $\delta_{\mathrm{H}} 1.72(2 \mathrm{H}, \mathrm{m}, \mathrm{H}-2), 3.09(2 \mathrm{H}, \mathrm{dd}, J=5.0,10.2 \mathrm{~Hz}, \mathrm{H}-8)$, $1.60(1 \mathrm{H}, \mathrm{m}, \mathrm{H}-12 \mathrm{a}), 1.44(1 \mathrm{H}, \mathrm{m}, \mathrm{H}-12 \mathrm{~b})$, and 1.27-1.28 (8H, m, overlapped, $\mathrm{H}-13-16)$. A detailed analysis of the ${ }^{13} \mathrm{C}-\mathrm{NMR}$ and DEPT spectra (Table 1 ) of compound 1 showed signals for two methyl groups at $\delta_{C} 9.5(\mathrm{C}-1)$ and $14.2(\mathrm{C}-17)$; two O-bearing methine carbons at $\delta_{\mathrm{C}} 64.1(\mathrm{C}-3)$ and $67.8(\mathrm{C}-11)$; two olefinic carbon resonances at $\delta_{C} 135.3$ (C-9) and 124.4 (C-10); and seven methylene carbons with chemical shifts ranging from 18.3 to $37.4 \mathrm{ppm}$. The abovementioned signals accounted for one degree of unsaturation, and thus, the remaining required the existence of two additional triple bonds in the molecule, which consisted of four quaternary carbons $\delta_{C} 77.3$ (C-4), 69.7 (C-5), 65.0 (C-6), and 78.6 (C-7) 
corresponding to the observed substitutions in the UV and IR spectra. By comparison, these data were relatively close to those of panaxjapyne A [6], except for the additional oxymethine at $\delta_{C} 67.8$ (C-11), which was clearly proven by the ${ }^{1} \mathrm{H}-{ }^{1} \mathrm{H}$ COSY correlations (Figure 2) of $\mathrm{H}-11$ with $\mathrm{H}-10$ and $\mathrm{H}-12$ and HMBC correlations (Figure 2) from H-11 to C-9, C-10, C-12, and C-13. Accordingly, compound 1 was elucidated as heptadeca-9-ene-4,6-diyne-3,11-diol.

Table 1. ${ }^{1} \mathrm{H}(500 \mathrm{MHz})$ and ${ }^{13} \mathrm{C}-\mathrm{NMR}(125 \mathrm{MHz})$ data for compounds $\mathbf{1}-\mathbf{3}$ in $\mathrm{CDCl}_{3}$ ( $\delta$ in ppm, $\mathrm{J}$ in $\left.\mathrm{Hz}\right)$.

\begin{tabular}{|c|c|c|c|c|c|c|}
\hline \multirow{2}{*}{ Position } & \multicolumn{2}{|l|}{1} & \multicolumn{2}{|l|}{2} & \multicolumn{2}{|l|}{3} \\
\hline & $\delta_{H}$ & $\delta_{C}$ & $\delta_{H}$ & $\delta_{C}$ & $\delta_{H}$ & $\delta_{C}$ \\
\hline 1 & $0.99, \mathrm{t}(7.4)$ & $9.5, \mathrm{CH}_{3}$ & $1.01, \mathrm{t}(7.4)$ & $9.5, \mathrm{CH}_{3}$ & $1.01, \mathrm{t}(7.4)$ & $9.5, \mathrm{CH}_{3}$ \\
\hline 2 & $1.72, \mathrm{~m}$ & $30.8, \mathrm{CH}_{2}$ & $1.75, \mathrm{~m}$ & $30.8, \mathrm{CH}_{2}$ & $1.73, \mathrm{~m}$ & $30.8, \mathrm{CH}_{2}$ \\
\hline 3 & $4.34, \mathrm{t}(6.4)$ & $64.1, \mathrm{CH}$ & $4.41, \mathrm{t}(6.5)$ & $64.3, \mathrm{CH}$ & $4.35, \mathrm{t}(6.4)$ & $64.2, \mathrm{CH}$ \\
\hline 4 & & $77.3, \mathrm{C}$ & & $83.5, \mathrm{C}$ & & $77.0, \mathrm{C}$ \\
\hline 5 & & 69.7, C & & $69.5, \mathrm{C}$ & & $69.8, \mathrm{C}$ \\
\hline 6 & & $65.0, \mathrm{C}$ & & $74.4, \mathrm{C}$ & & $66.3, \mathrm{C}$ \\
\hline 7 & & $78.6, \mathrm{C}$ & & 76.7, C & & $77.8, \mathrm{C}$ \\
\hline 8 & $3.09, \mathrm{dd}(5.0,10.2)$ & 18.3, $\mathrm{CH}_{2}$ & $5.86, \mathrm{~d}(15.9)$ & $110.5, \mathrm{CH}$ & $\begin{array}{l}\text { 2.51, dd }(17.3,6.1) \\
2.57, \mathrm{dd}(17.3,6.3)\end{array}$ & 24.8, $\mathrm{CH}_{2}$ \\
\hline 9 & 5.50, overlapped & 135.3, $\mathrm{CH}$ & 6.30, dd $(5.8,15.9)$ & $146.3, \mathrm{CH}$ & $3.70, \operatorname{td}(6.3,4.3)$ & 71.0, $\mathrm{CH}$ \\
\hline 10 & 5.48 , overlapped & $124.4, \mathrm{CH}$ & $4.00, \mathrm{td}(5.8,1.4)$ & $75.2, \mathrm{CH}$ & $3.24, \operatorname{td}(6.1,4.3)$ & $82.1, \mathrm{CH}$ \\
\hline 11 & $4.39 \mathrm{q}(6.7)$ & $67.8, \mathrm{CH}$ & $3.47, \mathrm{~m}$ & $74.4, \mathrm{CH}$ & $1.55, \mathrm{~m}$ & $29.9, \mathrm{CH}_{2}$ \\
\hline 12 & $1.60, \mathrm{~m} ; 1.44, \mathrm{~m}$ & $37.4, \mathrm{CH}_{2}$ & $1.46, \mathrm{~m}$ & $33.2, \mathrm{CH}_{2}$ & $1.28-1.29, \mathrm{~m}$ & $25.3, \mathrm{CH}_{2}$ \\
\hline 13 & $1.27-1.28, \mathrm{~m}$ & 25.3, $\mathrm{CH}_{2}$ & $1.27-1.28, \mathrm{~m}$ & 25.7, $\mathrm{CH}_{2}$ & $1.28-1.29, \mathrm{~m}$ & $29.4, \mathrm{CH}_{2}$ \\
\hline 14 & $1.27-1.28, \mathrm{~m}$ & $29.3, \mathrm{CH}_{2}$ & $1.27-1.28, \mathrm{~m}$ & $29.4, \mathrm{CH}_{2}$ & $1.28-1.29, \mathrm{~m}$ & $29.9, \mathrm{CH}_{2}$ \\
\hline 15 & $1.27-1.28, \mathrm{~m}$ & $31.9, \mathrm{CH}_{2}$ & $1.27-1.28, \mathrm{~m}$ & $31.9, \mathrm{CH}_{2}$ & $1.28-1.29, \mathrm{~m}$ & $31.9, \mathrm{CH}_{2}$ \\
\hline 16 & $1.27-1.28, \mathrm{~m}$ & $22.7, \mathrm{CH}_{2}$ & $1.27-1.28, \mathrm{~m}$ & $22.7, \mathrm{CH}_{2}$ & $1.28-1.29, \mathrm{~m}$ & $22.8, \mathrm{CH}_{2}$ \\
\hline 17 & 0.87 t $(6.8)$ & $14.2, \mathrm{CH}_{3}$ & 0.87 t (6.9) & $14.2, \mathrm{CH}_{3}$ & $0.88 \mathrm{t}(6.8)$ & $14.2, \mathrm{CH}_{3}$ \\
\hline$-\mathrm{OCH}_{3}$ & & & & & $3.42, \mathrm{~s}$ & $58.5, \mathrm{CH}_{3}$ \\
\hline
\end{tabular}
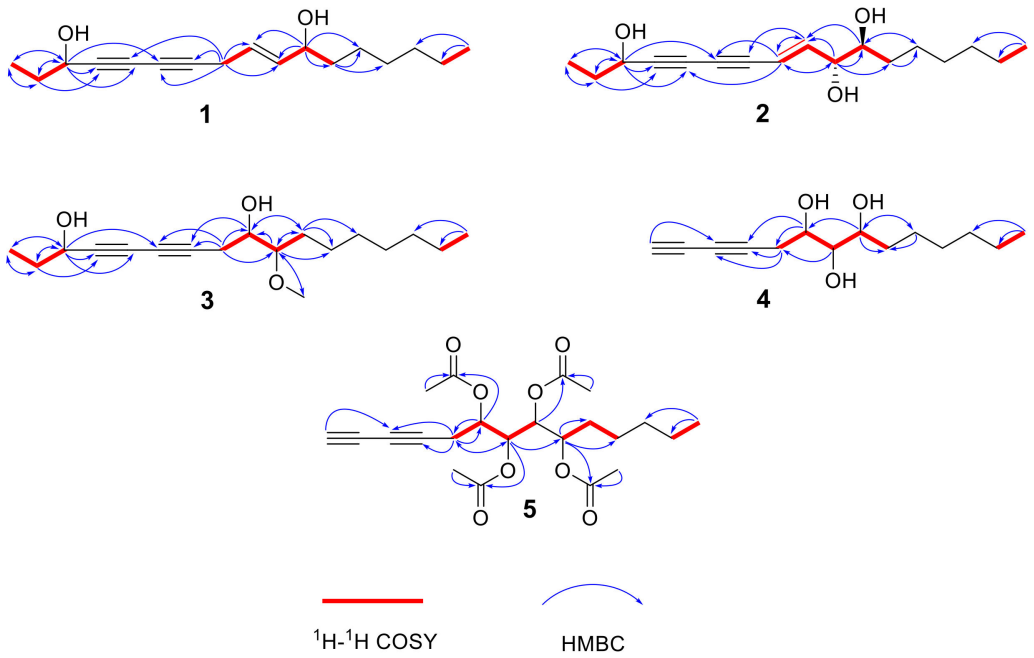

Figure 2. Key ${ }^{1} \mathrm{H}_{-}{ }^{1} \mathrm{H}$ COSY and HMBC correlations of compounds 1-5.

Compound 2 was separated as a yellow oil with a negative optical rotation $[\alpha]_{\mathrm{D}}^{25}-80$ (c 0.1, $\mathrm{CHCl}_{3}$ ), and its molecular formula was determined to be $\mathrm{C}_{17} \mathrm{H}_{26} \mathrm{O}_{3}$ by the HRESIMS peak at $\mathrm{m} / \mathrm{z}$ $301.1776[\mathrm{M}+\mathrm{Na}]^{+}$(calcd $\mathrm{C}_{17} \mathrm{H}_{26} \mathrm{NaO}_{3}$ for 301.1780). The ${ }^{1} \mathrm{H}-\mathrm{NMR}$ (Table 1) spectrum showed a pair of trans olefinic protons at $\delta_{\mathrm{H}} 6.30(1 \mathrm{H}, \mathrm{dd}, J=5.8,15.9 \mathrm{~Hz}, \mathrm{H}-9)$ and $5.86(1 \mathrm{H}, \mathrm{d}, J=15.9 \mathrm{~Hz}, \mathrm{H}-8)$; three oxymethine protons at $\delta_{\mathrm{H}} 4.41(1 \mathrm{H}, \mathrm{t}, J=6.5 \mathrm{~Hz}, \mathrm{H}-3), 4.00(1 \mathrm{H}, \mathrm{td}, J=5.8,1.4 \mathrm{~Hz}, \mathrm{H}-10)$, and 3.47 $(1 \mathrm{H}, \mathrm{m}, \mathrm{H}-11)$; and two methyl groups at $\delta_{\mathrm{H}} 1.01(3 \mathrm{H}, \mathrm{t}, J=7.4 \mathrm{~Hz}, \mathrm{H}-1)$ and $0.87(3 \mathrm{H}, \mathrm{t}, J=6.9 \mathrm{~Hz}$, $\mathrm{H}-17)$. A detailed analysis of the NMR spectroscopic spectra of compound 2 revealed that it is similar to panaxjapyne B [6] except for the additional oxymethine group in compound 2 . The ${ }^{1} \mathrm{H}_{-}{ }^{1} \mathrm{H}$ COSY correlations (Figure 2) of $\mathrm{H}-8 / \mathrm{H}-9 / \mathrm{H}-10 / \mathrm{H}-11 / \mathrm{H}-12$ and the HMBC correlations (Figure 2) from $\mathrm{H}-10$ to $\mathrm{C}-11$ and $\mathrm{C}-12$ and from $\mathrm{H}-11$ to $\mathrm{C}-9$ and $\mathrm{C}-13$ evidenced the location of oxymethine at C-11, 
which accounted for the molecular weight difference of 16 amu observed between the two compounds. Thus, the structure of compound 2 was elucidated as (E)-heptadeca-8-ene-4,6-diyne-3,10,11-triol. The relative configuration of C-10 and C-11 was determined by the ${ }^{3} J_{\mathrm{H}, \mathrm{H}}$ value and the ROESY interactions. The small ${ }^{3} J_{\mathrm{H}-10 / \mathrm{H}-11}$ value $(1.4 \mathrm{~Hz})$ was indicative of a gauche relationship of $\mathrm{H}-10$ and H-11 [34,35]. The ROESY correlations (Figure 3) of $\mathrm{H}-9 / \mathrm{H}-12 / \mathrm{H}-10 / \mathrm{H}-11$ suggested that the relative configurations of C-10 and C-11 were $R^{*}$ and $S^{*}$, respectively.

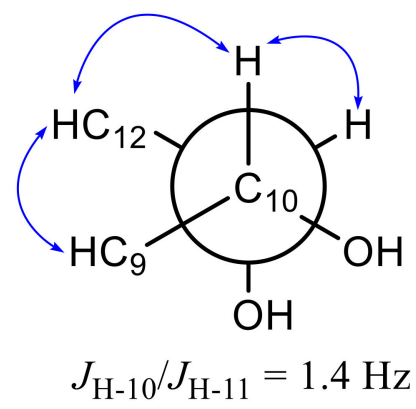

Figure 3. Key ROESY interactions of compound 2.

Compound 3 was separated as a yellow oil with a positive optical rotation $[\alpha]_{\mathrm{D}}^{25}+80\left(c 0.1, \mathrm{CHCl}_{3}\right)$. The molecular formula of compound 3 was established as $\mathrm{C}_{18} \mathrm{H}_{30} \mathrm{O}_{3}$ from the HRESIMS peak at $m / z$ 317.2089 [M + Na] $]^{+}$(calcd. $\mathrm{C}_{18} \mathrm{H}_{30} \mathrm{NaO}_{3}$ for 317.2093). The ${ }^{1} \mathrm{H}$ and ${ }^{13} \mathrm{C}-\mathrm{NMR}$ spectroscopic data (Table 1) of compound 3 were comparable to those of oploxyne B [5], suggesting that an oxidized methine of oploxyne B was replaced by the methylene $\left(\delta_{\mathrm{H}} 2.51,2.57 / \delta_{\mathrm{C}} 24.8\right)$ of compound 3 . Furthermore, the 16 amu of reduced molecular weight compared with oploxyne B indicated that the molecule formulas of the two compounds only differ by one oxygenium. The ${ }^{1} \mathrm{H}-{ }^{1} \mathrm{H}$ COSY correlations (Figure 2) of H-8/H-9/H-10/H-11 and the HMBC correlations (Figure 2) from H-8 to C-6, C-7, C-9, and C-10 implied that C-8 is the methylene carbon for compound 3. Finally, the structure of compound 3 was elucidated as 10-methoxyheptadeca-4,6-diyne-3,9-diol.

Compound 4 was obtained as a yellow oil with a negative optical rotation $[\alpha]_{\mathrm{D}}^{25}-80\left(c 0.1, \mathrm{CHCl}_{3}\right)$. The molecular formula was determined as $\mathrm{C}_{14} \mathrm{H}_{22} \mathrm{O}_{3}$ by the HRESIMS peak at $m / z 261.1476$ [M $\left.+\mathrm{Na}\right]^{+}$ (calcd for $\mathrm{C}_{14} \mathrm{H}_{22} \mathrm{NaO}_{3}, 261.1467$ ). The ${ }^{1} \mathrm{H}$ and ${ }^{13} \mathrm{C}-\mathrm{NMR}$ data (Table 2) showed three O-bearing methine groups at $\delta_{\mathrm{H}} 4.13(1 \mathrm{H}, \mathrm{br} \mathrm{t}, J=6.5 \mathrm{~Hz}, \mathrm{H}-6) / \delta_{\mathrm{C}}(69.6), 3.82(1 \mathrm{H}, \mathrm{m}, \mathrm{H}-8) / \delta_{\mathrm{C}}(75.1)$, and $3.49(1 \mathrm{H}$, $\mathrm{m}, \mathrm{H}-7) / \delta_{\mathrm{C}}(73.1)$; one triplet methyl group at $\delta_{\mathrm{H}} 0.89(3 \mathrm{H}, \mathrm{t}, J=6.7, \mathrm{H}-14) / \delta_{\mathrm{C}}(14.2)$; one acetylene $\mathrm{CH}$ group at $\delta_{\mathrm{H}} 2.00(1 \mathrm{H}, \mathrm{s}, \mathrm{H}-1) / \delta_{\mathrm{C}}(65.6)$; three quaternary carbon groups at $\delta_{\mathrm{C}} 68.2(\mathrm{C}-2), 67.0(\mathrm{C}-3)$, and 74.5 (C-4); and six methylenes at $\delta_{\mathrm{H}}(1.30-2.64) / \delta_{\mathrm{C}}(22.7-33.6)$. The ${ }^{1} \mathrm{H}$ and ${ }^{13} \mathrm{C}-\mathrm{NMR}$ spectroscopic

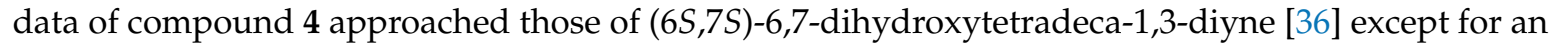
additional O-bearing methine in compound 4 . The structure was further elucidated by the HMBC and ${ }^{1} \mathrm{H}-{ }^{1} \mathrm{H}$ COSY data (Figure 2). The ${ }^{1} \mathrm{H}-{ }^{1} \mathrm{H}$ COSY correlations between $\mathrm{H}-5 / \mathrm{H}-6 / \mathrm{H}-7 / \mathrm{H}-8 / \mathrm{H}-9$, together with the HMBC correlations from H-8 to C-6, C-9 $\left(\delta_{C} 33.6\right)$, and C-10 $\left(\delta_{C} 26.0\right)$ and from H-6 to C-4 and $\mathrm{C}-5\left(\delta_{\mathrm{C}} 24.6\right)$ suggested that compound 4 has three successive O-bearing $\mathrm{CH}$ groups located at C-6, C-7, and C-8. Thus, the structure of compound 4 was elucidated as tetradeca-1,3-diyne-6,7,8-triol.

Compound 5 was obtained as a yellow oil with a negative optical rotation $[\alpha]_{\mathrm{D}}^{25}-16\left(c 0.1, \mathrm{CHCl}_{3}\right)$. The molecular formula was determined as $\mathrm{C}_{22} \mathrm{H}_{30} \mathrm{O}_{8}$ by the HRESIMS peak at $m / z 445.1859$ [M $\left.+\mathrm{Na}\right]^{+}$ (calcd for $\mathrm{C}_{22} \mathrm{H}_{30} \mathrm{NaO}_{8}, 445.1833$ ). The ${ }^{1} \mathrm{H}-\mathrm{NMR}$ spectrum (Table 2) showed four O-bearing methine groups at $\delta_{\mathrm{H}} 5.11(1 \mathrm{H}, \mathrm{q}, J=5.6 \mathrm{~Hz}, \mathrm{H}-6), 5.39(1 \mathrm{H}, \mathrm{dd}, J=4.7,6.2 \mathrm{~Hz}, \mathrm{H}-7), 5.18(1 \mathrm{H}, \mathrm{dd}, J=4.7$, $6.2 \mathrm{~Hz}, \mathrm{H}-8)$, and $5.07(1 \mathrm{H}, \mathrm{q}, J=6.4 \mathrm{~Hz}, \mathrm{H}-9)$; one triplet methyl group at $\delta_{\mathrm{H}} 0.86(3 \mathrm{H}, \mathrm{t}, J=6.9 \mathrm{~Hz}$, $\mathrm{H}-14)$; one acetylene $\mathrm{CH}$ group at $\delta_{\mathrm{H}} 2.00(1 \mathrm{H}, \mathrm{s}, \mathrm{H}-1) ; 10$ methylene protons at $\delta_{\mathrm{H}} 1.67-2.62$; and 12 acetoxy methyl protons at $\delta_{\mathrm{H}} 2.10-2.12$. The ${ }^{13} \mathrm{C}-\mathrm{NMR}$ and DEPT spectra indicated the presence of 22 carbons-one terminal methyl carbon at $\delta_{C} 14.1(\mathrm{C}-14)$; four O-bearing methine carbons at $\delta_{C} 69.1(\mathrm{C}-6), 70.6(\mathrm{C}-7), 71.2(\mathrm{C}-8)$, and $71.5(\mathrm{C}-9)$; three quaternary acetylenic carbons at $\delta_{C} 68.0$ $(\mathrm{C}-2), 67.6(\mathrm{C}-3)$, and $71.6(\mathrm{C}-4)$; one tertiary acetylenic carbon at $\delta_{C} 66.0(\mathrm{C}-1)$; and five methylene 
carbons at 21.8-31.5 ppm. All the assignments were supported by the HSQC experiments. A detailed comparison of the spectroscopic data of compounds $\mathbf{4}$ and $\mathbf{5}$ showed that in compound $\mathbf{5}$, there were four more acetyl groups $\left[\delta_{\mathrm{C}}(170.0-170.6) / \delta_{\mathrm{H}}(2.10-2.12)\right]$ and one more O-bearing methine than in compound 4. The ${ }^{1} \mathrm{H}-{ }^{1} \mathrm{H}$ COSY correlations (Figure 2) of $\mathrm{H}-5 / \mathrm{H}-6 / \mathrm{H}-7 / \mathrm{H}-8$ and $\mathrm{H}-9 / \mathrm{H}-10 / \mathrm{H}-11$, as well as the HMBC correlations (Figure 2) from H-6/H-6" to C-6' (170.1), from H-7/H-7" to C-7' (170.0), from H-8/H-8" to C-8' (170.3), and from H-9/H-9" to C-9 (170.6), indicated that compound 5 has four acetyls linked to C-6, C-7, C-8, and C-9, respectively. The other key correlations of HMBC and ${ }^{1} \mathrm{H}-{ }^{1} \mathrm{H}$ COSY are shown in Figure 2. Thus, the planar structure of compound $\mathbf{5}$ was elucidated as 6,7,8,9-tetraacetoxytetradeca-1,3-diyne.

Table 2. ${ }^{1} \mathrm{H}(500 \mathrm{MHz})$ and ${ }^{13} \mathrm{C}-\mathrm{NMR}(125 \mathrm{MHz})$ data for compounds 4 and 5 in $\mathrm{CDCl}_{3}(\delta$ in ppm, $J$ in $\mathrm{Hz})$.

\begin{tabular}{|c|c|c|c|c|c|c|c|}
\hline Position & \multicolumn{2}{|l|}{4} & \multicolumn{5}{|c|}{5} \\
\hline 1 & $2.00, \mathrm{~s}$ & $65.6, \mathrm{CH}$ & $2.00, \mathrm{~s}$ & $66.0, \mathrm{CH}$ & $6^{\prime}$ & & $170.1, \mathrm{C}$ \\
\hline 3 & & $67.0, \mathrm{C}$ & & $67.6, \mathrm{C}$ & $8^{\prime}$ & & $170.3, \mathrm{C}$ \\
\hline 4 & & $74.5, \mathrm{C}$ & & $71.6, \mathrm{C}$ & $9^{\prime}$ & & $170.6, \mathrm{C}$ \\
\hline 6 & 4.13, br t $(6.5)$ & 69.6, CH & $5.11, \mathrm{q}(5.6)$ & $69.1, \mathrm{CH}$ & $7^{\prime \prime}$ & $2.12^{\mathrm{b}}, \mathrm{s}$ & $21.0^{\mathrm{a}}, \mathrm{CH}_{3}$ \\
\hline 7 & $3.49, \mathrm{~m}$ & $73.1, \mathrm{CH}$ & $5.39, \mathrm{dd}(4.7,6.2)$ & $70.6, \mathrm{CH}$ & $8^{\prime \prime}$ & $2.10^{\mathrm{b}}, \mathrm{s}$ & $20.9^{\mathrm{a}}, \mathrm{CH}_{3}$ \\
\hline 8 & $3.82, \mathrm{~m}$ & $75.1, \mathrm{CH}$ & $5.18, \mathrm{dd}(4.7,6.2)$ & $71.2, \mathrm{CH}$ & $9^{\prime \prime}$ & $2.10^{\mathrm{b}}, \mathrm{s}$ & $20.8^{\mathrm{a}}, \mathrm{CH}_{3}$ \\
\hline 9 & $1.55, \mathrm{~m}$ & $33.6, \mathrm{CH}_{2}$ & $5.07, \mathrm{q}(6.4)$ & $71.5, \mathrm{CH}$ & & & \\
\hline 10 & $1.33, \mathrm{~m} 1.55, \mathrm{~m}$ & $26.0, \mathrm{CH}_{2}$ & $1.55, \mathrm{~m}$ & $30.6, \mathrm{CH}_{2}$ & & & \\
\hline
\end{tabular}

Due to the high flexibly of the carbon chains, crystals were not obtained from compounds 1-5. Furthermore, the triple bonds contained compounds that were unstable and highly reactive [1], which resulted in all the isolates being chemically changed via oxidation and degradation. Therefore, the configurations of compounds 1-5 were not elucidated because of the materials' instability and were reported as shown in Figure 1.

Compounds 1-7 were assessed for cytotoxic activity in the BEL-7402, K562, and SGC-7901 cancer cell lines, respectively. The results show that compounds 1 and $\mathbf{6}$ exhibited cytotoxicity in the above three human cancer lines, ranging from 14.3 to $45.4 \mu \mathrm{M}$ (Table 3). Contrastingly, compound 4 displayed weak cytotoxicity in SGC-7901 and $\mathrm{K} 562$, with $\mathrm{IC}_{50}$ values of $26.2 \pm 0.4$ and $21.9 \pm 0.3 \mu \mathrm{M}$, respectively. By comparison, the cytotoxicity in BEL-7401 and SGC-7901 was slightly enhanced when the double bond between C-9 and C-10 in compound 1 was oxidized to the epoxy group in compound 6 , which could be due to the highly genotoxic effect of the epoxy group [37,38].

Table 3. Cytotoxicity of compounds 1-7 in the human cancer cell lines.

\begin{tabular}{cccc}
\hline \multirow{2}{*}{ Compound } & \multicolumn{3}{c}{ Cell Line, IC $_{50}(\boldsymbol{\mu M})$} \\
\cline { 2 - 4 } & BEL-7402 & SGC-7901 & K562 \\
\hline $\mathbf{1}$ & $24.9 \pm 0.3$ & $45.4 \pm 0.6$ & $16.8 \pm 0.1$ \\
$\mathbf{4}$ & $>50$ & $26.2 \pm 0.4$ & $21.9 \pm 0.3$ \\
$\mathbf{6}$ & $14.3 \pm 0.4$ & $33.4 \pm 0.6$ & $16.6 \pm 0.4$ \\
$\mathbf{2}, \mathbf{3}, \mathbf{5}, \mathbf{7}$ & $>50$ & $>50$ & $>50$ \\
Paclitaxel $^{\text {a }}$ & $4.3 \pm 0.1$ & $4.3 \pm 0.2$ & $8.6 \pm 0.1$ \\
\hline
\end{tabular}

a Positive control. 


\section{Materials and Methods}

\subsection{General Experimental Procedures}

The ${ }^{1} \mathrm{H},{ }^{13} \mathrm{C}$, and 2D NMR spectra were recorded on a Bruker AV III spectrometer (Bruker, Bremen, Germany) at either $500 \mathrm{MHz}\left({ }^{1} \mathrm{H}\right)$ or $125 \mathrm{MHz}\left({ }^{13} \mathrm{C}\right)$ using TMS as an internal standard. The HRMS were measured with an API QSTAR Pulsar mass spectrometer (Bruker). The UV spectra were performed on a Shimadzu UV-2550 spectrometer (Beckman, Brea, CA, USA). The IR absorptions were obtained on a Nicolet 380 FT-IR instrument (Thermo, Pittsburgh, PA, USA) using KBr pellets. The optical rotation was measured on a Rudolph Autopol III polarimeter (Rudolph, Hackettstown, NJ, USA). Silica gel (60-80, 200-300 mesh, Qingdao Marine Chemical Co. Ltd., Qingdao, China), ODS gel (20-45 $\mu$ m, Fuji Silysia Chemical Co. Ltd., Durham, NC, USA), and Sephadex LH-20 (Merck, Darmstadt, Germany) were used for column chromatography. The TLC was conducted on pre-coated silica gel G plates (Qingdao Marine Chemical Co. Ltd.), and spots were detected by spraying with $10 \% \mathrm{H}_{2} \mathrm{SO}_{4}$ in $\mathrm{EtOH}$ followed by heating.

\subsection{Plant Material}

The plant material was collected at the Chinese Academy of Tropical Agricultural Sciences, Haikou, China, in April 2014 and was identified as Swietenia macrophylla by Dr. Jun Wang (Institute of Tropical Bioscience and Biotechnology, Chinese Academy of Tropical Agricultural Sciences). The voucher specimen (No. DYTHXM201404) was deposited at the Institute of Tropical Bioscience and Biotechnology, Chinese Academy of Tropical Agricultural Science.

\subsection{Extraction and Isolation}

The roots of $S$. macrophylla $(57.0 \mathrm{~kg}$, dry weight) were first crushed and extracted with $95 \%$ $\mathrm{EtOH}(3 \times 150.0 \mathrm{~L})$ at room temperature and evaporated to yield EtOH extract $(8.0 \mathrm{~kg})$, which was then partitioned with $\mathrm{H}_{2} \mathrm{O}(40.0 \mathrm{~L})$ and extracted with petroleum ether $(\mathrm{PE})(40.0 \mathrm{~L} \times 3)$ and EtOAc $(40.0 \mathrm{~L} \times 3)$, respectively. The EtOAc extract $(3931.0 \mathrm{~g})$ was subjected to silica gel $(20 \times 50 \mathrm{~cm}, 12.0 \mathrm{~kg})$ vacuum liquid chromatography, and eluted with $\mathrm{CHCl}_{3} / \mathrm{MeOH}(v / v, 10: 1 ; 40.0 \mathrm{~L})$ to obtain fraction 1 (Fr.1). Silica gel $(10 \times 50 \mathrm{~cm}, 2.0 \mathrm{~kg})$ vacuum liquid chromatography of Fr.1 (573.0 g) was eluted with PE/EtOAc $\left(v / v, 1: 0,100: 1,50: 1,25: 1,10: 1,5: 1\right.$, each 5.0 L, gradient) and $\mathrm{CHCl}_{3} / \mathrm{MeOH}(v / v, 1: 0$, 100:1, 50:1, 25:1, 10:1, 5:1, 0:1, each 5.0 L, gradient), respectively, which resulted in 17 sub-fractions (Fr.1.1-Fr.1.17). Fr.1.8 (19.5 g) was applied to an ODS gel $(4.5 \times 40 \mathrm{~cm})$ and eluted with $\mathrm{MeOH} / \mathrm{H}_{2} \mathrm{O}$ $(v / v, 3: 7,2: 3,1: 1,3: 2,7: 3,4: 1,9: 1,1: 0$, each 5.0 L) to yield Fr.1.8.1-10. Fr.1.8.5 (2.9 g) was separated on a Sephadex LH-20 $(3 \times 100 \mathrm{~cm})$ with $\mathrm{CHCl}_{3} / \mathrm{MeOH}$ as the eluent $(v / v, 1: 1 ; 1.5 \mathrm{~L})$ to give Fr.1.8.5.1-5. Fr.1.8.5.1 (1.6 g) was separated on a silica gel column $(3 \times 45 \mathrm{~cm}, 160 \mathrm{~g})$ and eluted with PE/EtOAc $(v / v, 12: 1)$ to yield compound $1(30.0 \mathrm{mg})$ before it was eluted with a gradient of PE/acetone $(v / v, 20: 1$, 15:1, 5:1, 1:1, 0.6 L of each) to give six fractions (Fr.1.8.5.1.1-6). Compound 7 (2.2 mg) from Fr.1.8.5.1.1 $(32.0 \mathrm{mg})$ was obtained from a silica gel $(1 \times 12 \mathrm{~cm}, 6 \mathrm{~g})$ eluting with PE/EtOAc $(v / v, 8: 1)$. Compound $6(30.0 \mathrm{mg})$ from Fr.1.8.5.1.2 (380.0 mg) was obtained from a silica gel $(2 \times 30 \mathrm{~cm}, 60.0 \mathrm{~g})$ eluting with $\mathrm{PE} / \mathrm{CHCl}_{3}(v / v, 1: 1)$. Fr. 1.8.5.1.3 $(150.0 \mathrm{mg})$ was subjected to a silica gel $(1 \times 25 \mathrm{~cm}, 15.0 \mathrm{~g})$ with $\mathrm{PE} / \operatorname{EtOAc}(v / v, 5: 1)$ to obtain compound $3(8.0 \mathrm{mg})$. Fr. 1.8.5.1.4 (180.6 $\mathrm{mg})$ was applied to a silica gel $(1 \times 30 \mathrm{~cm}, 18.0 \mathrm{~g})$ eluting with PE/EtOAc $(v / v, 4: 1)$ to yield compound 2 (14.8 mg). Fr. 1.8.5.1.5 $(121.4 \mathrm{mg})$ was purified by a silica gel $(1 \times 30 \mathrm{~cm}, 20.0 \mathrm{~g})$ eluting with $\mathrm{CHCl}_{3} /$ acetone $(v / v, 5: 1)$ to obtain compounds 5 (1.2 mg) and 4 (3.8 mg).

Heptadeca-9-ene-4,6-diyne-3,11-diol (1): yellow oil; UV ( $\left.\mathrm{CH}_{3} \mathrm{OH}\right) \lambda_{\max }(\log \varepsilon) 280$ (2.90), 270 (2.98) nm; IR $(\mathrm{KBr}) v_{\max } 3435,2924,2234,1639,1384,1020 \mathrm{~cm}^{-1} ;[\alpha]_{\mathrm{D}}^{25}+10\left(c 0.1, \mathrm{CH}_{3} \mathrm{OH}\right) ;{ }^{1} \mathrm{H}$ and ${ }^{13} \mathrm{C}-\mathrm{NMR}$ data: Table 1; HRESIMS $m / z 285.1830$ [M + Na] ${ }^{+}$(calcd. $\mathrm{C}_{17} \mathrm{H}_{26} \mathrm{NaO}_{2}$ for 285.1831). 
(E)-Heptadeca-8-ene-4,6-diyne-3,10,11-triol (2): yellow oil; UV ( $\left.\mathrm{CHCl}_{3}\right) \lambda_{\max }(\log \varepsilon) 286$ (3.60), 270 (3.68) $\mathrm{nm}$; IR (KBr) $\nu_{\max } 3433,2927,2250,1645,1382,1026 \mathrm{~cm}^{-1} ;[\alpha]_{\mathrm{D}}^{25}-80\left(c 0.1, \mathrm{CHCl}_{3}\right) ;{ }^{1} \mathrm{H}$ and ${ }^{13} \mathrm{C}-\mathrm{NMR}$ data: Table 1; HRESIMS $m / z 301.1776[\mathrm{M}+\mathrm{Na}]^{+}$(calcd. $\mathrm{C}_{17} \mathrm{H}_{26} \mathrm{NaO}_{3}$ for 301.1780).

10-Methoxyheptadeca-4,6-diyne-3,9-diol (3): yellow oil; UV $\left(\mathrm{CHCl}_{3}\right) \lambda_{\max }(\log \varepsilon) 286$ (2.77), 270 (2.78) $\mathrm{nm}$; IR (KBr) $v_{\max } 3432,2929,2245,1388,1028 \mathrm{~cm}^{-1} ;[\alpha]_{\mathrm{D}}^{25}+80\left(c 0.1, \mathrm{CHCl}_{3}\right) ;{ }^{1} \mathrm{H}$ and ${ }^{13} \mathrm{C}-\mathrm{NMR}$ data: Table 1; HRESIMS m/z 317.2089 [M + Na] ${ }^{+}$(calcd. $\mathrm{C}_{18} \mathrm{H}_{30} \mathrm{NaO}_{3}$ for 317.2093).

Tetradeca-1,3-diyne-6,7,8-triol (4): yellow oil; UV $\left(\mathrm{CHCl}_{3}\right) \lambda_{\max }(\log \varepsilon) 298$ (1.32), 240 (2.60) nm; IR (KBr) $\nu_{\max } 3434,2926,2241,1384,1018 \mathrm{~cm}^{-1} ;[\alpha]_{\mathrm{D}}^{25}-80\left(c 0.1, \mathrm{CHCl}_{3}\right) ;{ }^{1} \mathrm{H}$ and ${ }^{13} \mathrm{C}-\mathrm{NMR}$ data: Table 2; HREIMS $m / z 261.1476[\mathrm{M}+\mathrm{Na}]^{+}$(calcd for $\mathrm{C}_{14} \mathrm{H}_{22} \mathrm{NaO}_{3}, 261.1467$ ).

6,7,8,9-Tetraacetoxytetradeca-1,3-diyne (5): yellow oil; UV $\left(\mathrm{CHCl}_{3}\right) \lambda_{\max }(\log \varepsilon) 212(4.44), 271$ (3.55), 308 (3.12) nm; IR (KBr) $v_{\max } 2924,2233,1741,1634,1460,1090 \mathrm{~cm}^{-1} ;[\alpha]_{\mathrm{D}}^{25}-16\left(c 0.1, \mathrm{CHCl}_{3}\right) ;{ }^{1} \mathrm{H}$ and ${ }^{13} \mathrm{C}-\mathrm{NMR}$ data: Table 2; HREIMS $m / z 445.1859[\mathrm{M}+\mathrm{Na}]^{+}$(calcd for $\mathrm{C}_{22} \mathrm{H}_{30} \mathrm{NaO}_{8}, 445.1833$ ).

\subsection{Bioassay of Cytotoxic Activity}

MTT assay, originally described by Mosmann [39], was used to quantitate the cytotoxicity of compounds 1-7. The human hepatocellular carcinoma cell line BEL-7402, human myeloid leukemia cell line K562, and human gastric carcinoma cell line SGC-7901, which were obtained from the cell bank of type culture collection of the Chinese Academy of Sciences, Shanghai Institute of Cell Biology, were cultured in RPMI 1640 medium supplemented with 10\% fetal bovine serum at the conditions of $37^{\circ} \mathrm{C}, 5 \% \mathrm{CO}_{2}$, and $90 \%$ humidity. Paclitaxel was used as the positive control and DMSO was used as the negative control. Different concentrations of the test sample (each had triplicate wells) were designed as $0.1,0.4,1.6,6.3,25$, and $100 \mu \mathrm{M}$. The logarithmic phase cells $(90 \mu \mathrm{L})$ were selected to seed onto the 96 -well plates at a concentration of $5 \times 10^{4}$ cell $/ \mathrm{mL}$. Then, $15 \mu \mathrm{L}$ of MTT dissolved in PBS at $5 \mathrm{mg} / \mathrm{mL}$ was added to each well, and the system was incubated at $37^{\circ} \mathrm{C}$ for $4 \mathrm{~h}$. After that, the supernatant was discarded, and $100 \mu \mathrm{L}$ of DMSO was added into each well. Finally, the OD value was measured by a MK3 Microtiter plate reader at a wavelength of $490 \mathrm{~nm}$.

\section{Conclusions}

Seven polyacetylenes were isolated from the roots of S. macrophylla. Their structures were determined by spectroscopic analysis and comparing data in the literature. Furthermore, compounds 1 and $\mathbf{6}$ displayed weak cytotoxicity in the BEL-7402, SGC-7901, and K562 cell lines, and compound 4 showed a weak cytotoxic effect in the SGC-7901 and K562 cell lines.

Supplementary Materials: HRESIMS and NMR spectra for compounds 1-5 are available online.

Author Contributions: The list authors contributed to this work as follows: C.-N.M. processed the data, collected the plant samples, and prepared the manuscript. C.-N.M. and H.W. contributed to the structural elucidation. W.-L.M., H.-Q.C., and H.W. contributed to the revision of this manuscript. C.-H.C. and S.-P.L. conducted the bioassay experiments. The research was performed based on the planning of H.-F.D. and W.-L.M. All the authors approved the final version of the manuscript. Conceptualization, S.-P.L., W.-L.M., and H.-F.D.; Data curation, C.-N.M. and C.-H.C.; Formal analysis, H.W. and H.-Q.C.; Methodology, C.-N.M.; Project administration, W.-L.M. and H.-F.D.; Resources, W.-L.M. and H.-F.D.; Supervision, H.-Q.C., S.-P.L., W.-L.M., and H.-F.D.; Validation, H.W., H.-Q.C., and C.-H.C.; Original draft preparation, and C.-N.M.; and Review and editing of the manuscript, H.W.

Funding: This research was funded by the Innovative Research Team Grant of the Natural Science Foundation of Hainan Province (No. 2017CXTD020) and the Central Public-interest Scientific Institution Basal Research Fund for Chinese Academy of Tropical Agricultural Sciences (No. 17CXTD-15).

Conflicts of Interest: The authors declare no conflicts of interest.

\section{References}

1. Konovalov, D.A. Polyacetylene compounds of plants of the Asteraceae, Family (Review). Pharm. Chem. J. 2014, 48, 613-631. 
2. Hansen, L.; Boll, P.M. Polyacetylenes in Araliaceae: Their chemistry, biosynthesis and biological significance. Phytochemistry 1986, 25, 285-293. [CrossRef]

3. Hirakura, K.; Morita, M.; Nakajima, K.; Ikeya, Y.; Mitsuhashi, H. Three acetylated polyacetylenes from the roots of Panax ginseng. Phytochemistry 1991, 30, 3327-3333. [CrossRef]

4. Hirakura, K.; Morita, M.; Nakajima, K.; Ikeya, Y.; Mitsuhashi, H. Three acetylenic compounds from roots of Panax ginseng. Phytochemistry 1992, 31, 899-903. [CrossRef]

5. Yang, M.C.; Hakcheol, K.; Youngjoo, K.; Kangro, L.; Yang, H.O. Oploxynes A and B, polyacetylenes from the stems of Oplopanax elatus. J. Nat. Prod. 2010, 73, 801-805. [CrossRef] [PubMed]

6. Chan, H.H.; Sun, H.D.; Reddy, M.V.; Wu, T.S. Potent alpha-glucosidase inhibitors from the roots of Panax japonicus C. A. Meyer var. major. Phytochemistry 2010, 71, 1360-1364. [CrossRef]

7. Wang, C.Z.; Zhang, Z.Y.; Huang, W.H.; Du, G.J.; Wen, X.D.; Calway, T.; Yu, C.H.; Nass, R.; Zhao, J.; $\mathrm{Du}, \mathrm{W}$; et al. Identification of potential anticancer compounds from Oplopanax horridus. Phytomedicine 2013, 20, 999-1006. [CrossRef]

8. Chicca, A.; Pellati, F.; Adinolfi, B.; Matthias, A.; Massarelli, I.; Benvenuti, S.; Martinotti, E.; Bianucci, A.M.; Bone, K.; Lehmann, R.; et al. Cytotoxic activity of polyacetylenes and polyenes isolated from roots of Echinacea pallida. Brit. J. Pharmacol. 2008, 153, 879-885. [CrossRef]

9. Quintana, N.; Weir, T.L.; Du, J.; Broeckling, C.D.; Rieder, J.P.; Stermitz, F.R.; Paschke, M.W.; Vivanco, J.M. Phytotoxic polyacetylenes from roots of Russian knapweed (Acroptilon repens (L.) DC.). Phytochemistry 2008, 69, 2572-2578. [CrossRef]

10. Jung, H.J.; Min, B.S.; Park, J.Y.; Kim, Y.H.; Lee, H.K.; Bae, K.H. Gymnasterkoreaynes A-F, cytotoxic polyacetylenes from Gymnaster koraiensis. J. Nat. Prod. 2002, 65, 897-901. [CrossRef]

11. Huang, H.Q.; Zhang, X.; Shen, Y.H.; Su, J.; Liu, X.H.; Tian, J.M.; Lin, S.; Shan, L.; Zhang, W.D. Polyacetylenes from Bupleurum longiradiatum. J. Nat. Prod. 2009, 72, 2153-2157.

12. Bentley, R.K.; Jenkins, J.K.; Jones, E.R.H.; Thaller, V. Natural acetylenes. Part XXIX. Polyacetylenes from the Campanulaceae plant family. Tetrahydropyranyl polyacetylenic alcohols from the clustered bellflower (Campanula glomerata L.). J. Chem. Soc. C Organ. 1969, 5, 830-832. [CrossRef]

13. Ishimaru, K.; Osabe, M.; Yan, L.; Fujioka, T.; Mihashi, K.; Tanaka, N. Polyacetylene glycosides from Pratia nummularia cultures. Phytochemistry 2003, 62, 643-646. [CrossRef]

14. Koch, M.; Bugni, T.S.; Pond, C.D.; Sondossi, M.; Dindi, M.; Piskaut, P.; Ireland, C.M.; Barrows, L.R. Antimycobacterial activity of Exocarpos latifolius is due to exocarpic acid. Planta Med. 2009, 75, 1326-1330. [CrossRef]

15. Bohlmann, F.; Rode, K.M. Polyacetylenverbindungen, 150. Notiz über die Polyineaus Pittosporum buchanani Hook. Fil. Eur. J. Inorg. Chem. 2010, 101, 1889-1891.

16. Marles, R.J.; Farnsworth, N.R.; Neill, D.A. Isolation of a novel cytotoxic polyacetylene from a traditional anthelmintic medicinal plant, Minquartia guianensis. J. Nat. Prod. 1989, 52, 261-266. [CrossRef]

17. Wakabayashi, N.; Spencer, S.L.; Waters, R.M.; Lusby, W.R. A Polyacetylene from Honduras Mahogany, Swietenia mahagoni. J. Nat. Prod. 1991, 54, 1419-1421. [CrossRef]

18. Ning, J.; Di, Y.T.; Li, S.F.; Geng, Z.L.; He, H.P.; Wang, Y.H.; Wang, Y.Y.; Li, Y.; Li, S.L.; Hao, X.J. Polyynes from Toona ciliata var. ciliata and related cytotoxic activity. Helv. Chim. Acta 2011, 94, 376-381. [CrossRef]

19. Zhang, B.; Wang, Y.; Yang, S.P.; Zhou, Y.; Wu, W.B.; Tang, W.; Zuo, J.P.; Li, Y.; Yue, J.M. Ivorenolide A, an unprecedented immunosuppressive macrolide from Khaya ivorensis: structural elucidation and bioinspired total synthesis. J. Am. Chem. Soc. 2012, 134, 20605-20608. [CrossRef] [PubMed]

20. Wang, Y.; Liu, Q.F.; Xue, J.J.; Zhou, Y.; Yu, H.C.; Yang, S.Y.; Zhang, B.; Zuo, J.P.; Li, Y.; Yue, J.M. Ivorenolide B, an immunosuppressive 17-membered macrolide from Khaya ivorensis: structural determination and total synthesis. Org. Lett. 2014, 16, 2062-2065. [CrossRef] [PubMed]

21. Bernart, M.W.; Ii, J.H.C.; Balaschak, M.S.; Alexander, M.R.; Shoemaker, R.H.; Boyd, M.R. Cytotoxic falcarinol oxylipins from Dendropanax arboreus. J. Nat. Prod. 1996, 59, 748-753. [CrossRef]

22. Koch, M.; Bugni, T.S.; Sondossi, M.; Ireland, C.M.; Barrows, L.R. Exocarpic acid inhibits mycolic acid biosynthesis in Mycobacterium tuberculosis. Planta Med. 2010, 76, 1678-1682. [CrossRef] [PubMed]

23. Kobaisy, M.; Abramowski, Z.; Lermer, L.; Saxena, G.; Hancock, R.E.; Towers, G.H.; Doxsee, D.; Stokes, R.W. Antimycobacterial polyynes of Devil's Club (Oplopanax horridus), a North American native medicinal plant. J. Nat. Prod. 1997, 60, 1210-1213. [CrossRef] 
24. Sara, I.; Yoel, K.; Shoshana, L.; Amnon, H.; Yossi, L. Petrosynol and petrosolic acid, two novel natural inhibitors of the reverse transcriptase of human immundeficiency virus from Petrosia sp. Tetrahedron 1993, 49, 10435-10438.

25. Fusetani, N.; Sugano, M.; Matsunaga, S.; Hashimoto, K. H, K-ATPase inhibitors from the marine sponge siphonochalinatruncata: Absolute configuration of siphonodiol and two related metabolites. Tetrahedron Lett. 1987, 28, 4311-4312. [CrossRef]

26. Pennington, T.D. Mahogany carving a future. Biologist 2002, 49, 204. [PubMed]

27. Paiva, E.A. Anatomy, ultrastructure, and secretory activity of the floral nectaries in Swietenia macrophylla (Meliaceae). Am. J. Bot. 2012, 99, 1910-1917. [CrossRef] [PubMed]

28. Chen, S.K.; Chen, B.Y.; Li, H. Flora of China; Science Press: Beijing, China, 1997.

29. Mulholland, D.A.; Parel, B.; Coombes, P.H. The chemistry of the Meliaceae and Ptaeroxylaceae of Southern and Eastern Africa and Madagascar. Curr. Org. Chem. 2000, 4, 1011-1054. [CrossRef]

30. Tan, Q.G.; Luo, X.D. Meliaceous limonoids: Chemistry and biological activities. Chem. Rev. 2011, 111, 7437-7522. [CrossRef]

31. Sun, Y.P.; Jin, W.F.; Wang, Y.Y.; Wang, G.; Morris-Natschke, S.L.; Liu, J.S.; Wang, G.K.; Lee, K.H. Chemical structures and biological activities of limonoids from the genus Swietenia (Meliaceae). Molecules 2018, 23, 1588. [CrossRef] [PubMed]

32. Mi, C.N.; Mei, W.L.; Li, W.; Wang, J.; Cai, C.H.; Li, S.P.; Dai, H.F. Chemical constituents from the roots of Swietenia macrophylla King. J. Trop. Subtrop. Bot. 2017, 25, 610-616.

33. Mi, C.N.; Li, W.; Chen, H.Q.; Wang, J.; Cai, C.H.; Li, S.P.; Mei, W.L.; Dai, H.F. Two new compounds from the roots of Swietenia macrophylla. J. Asian. Nat. Prod. Res. 2018. [CrossRef] [PubMed]

34. Matsumori, N.; Kaneno, D.; Murata, M.; Nakamura, H.; Tachibana, K. Stereochemical determination of acyclic structures based on carbon-proton spin-coupling constants. A method of configuration analysis for natural products. J. Org. Chem. 1999, 64, 866-876. [CrossRef]

35. Wu, Q.; Wu, C.M.; Long, H.L.; Chen, R.; Liu, D.; Proksch, P.; Guo, P.; Lin, W.H. Varioxiranols A-G and 19-O-methyl-22-methoxypre-shamixanthone, PKS and hybrid PKS-derived metabolites from a Sponge-associated Emericella variecolor Fungus. J. Nat. Prod. 2015, 78, 2461-2470. [CrossRef]

36. Satoh, M.; Takeuchi, N.; Fujimoto, Y. Synthesis and absolute configuration of Panaxytriol. Chem. Pharm. Bull. 1997, 45, 1114-1116. [CrossRef]

37. Lajovic, A.; Nagy, L.D.; Guengerich, F.P.; Bren, U. Carcinogenesis of urethane: simulation versus experiment. Chem. Res. Toxicol. 2015, 28, 691-701. [CrossRef]

38. Klvana, M.; Bren, U. Aflatoxin $B_{1}$-formamidopyrimidine DNA adducts: Relationships between structures, free energies, and melting temperatures. Molecules 2019, 24, 150. [CrossRef] [PubMed]

39. Mosmann, T. Rapid colorimetric assay for cellular growth and survival: Application to proliferation and cytotoxicity assays. J. Immunol. Methods 1983, 65, 55-63. [CrossRef]

Sample Availability: Not available.

(C) 2019 by the authors. Licensee MDPI, Basel, Switzerland. This article is an open access article distributed under the terms and conditions of the Creative Commons Attribution (CC BY) license (http://creativecommons.org/licenses/by/4.0/). 